\title{
PENGEMBANGAN DESA WISATA SEBALOR MENJADI DAERAH TUJUAN WISATA
}

\section{DEVELOPMENT OF SEBALOR TOURISM VILLAGE INTO A TOURISM DESTINATION AREA}

\author{
Andri Wahyudi, Fahrul Firdaus \\ Program Studi Administrasi Publik, Fakultas Ilmu Sosial dan Ilmu Politik, Universitas \\ Tulungagung, Indonesia \\ Program Studi Administrasi Publik, Fakultas Ilmu Sosial dan Ilmu Politik, Universitas \\ Tulungagung, Indonesia
}

\section{andriwahvudi1964@gmail.com, fhovaghavig@gmail.com}

\begin{abstract}
ABSTRAK
Pengembangan Desa Wisata Sebalor menjadi Daerah Tujuan Wisata (DTW) tidak terlepas dari kemauan serta keterlibatan/ partisipasi masyarakat yang ada di desa tersebut secara langsung maupun tidak langsung. Penelitian ini bertujuan untuk memotret kemauan, keterlibatan/ partisipasi masyarakat dalam pengembangan Desa Wisata Sebalor menjadi Daerah Tujuan Wisata. Rumusan masalah dalam Penelitian ini adalah : Bagaimana Pengembangan Desa Wisata Sebalor menjadi Daerah Tujuan Wisata (DTW) dan juga ingin mengungkap beberapa hal yang dimungkinkan dapat menjadi faktor pendorong dan penghambat Pengembangan Desa Wisata Sebalor menjadi Daerah Tujuan Wisata (DTW) di kawasan Kecamatan Bandung Kabupaten Tulungagung. Metode penelitian dalam penelitian ini termasuk metode deskreptif sedangkan jenis penelitiannya adalah termasuk dalam penelitian kualitatif. Pengumpulan data dilakukan dengan menggunakan metode observasi, wawancara, dan dokumentasi. Subjek dalam penelitian ini adalah Pemerintah Desa Sebalor, Masyarakat Desa Sebalor, Pengunjung Kali Mas dan Watu Gedong. Selanjutnya analisa data dalam penelitian ini dilakukan dengan menggunakan analisa kualitatif dengan langkah-langkah reduksi data, penyajian data dan
\end{abstract}


penarikan kesimpulan. Keabsahan data dalam penelitian ini meliputi 1) uji kredibility, 2) uji transferability, 3) uji dependability, 4) uji konfirmability.

\title{
Kata Kunci : Pengembangan Desa Wisata Sebalor, Daerah Tujuan Wisata
}

\begin{abstract}
The development of Sebalor Tourism Village into a Tourist Destination Area (DTW) cannot be separated from the will and involvement/participation of the community in the village directly or indirectly. This study aims to capture the willingness, involvement/participation of the community in the development of the Sebalor Tourism Village into a Tourist Destination Area. The formulation of the problem in this research is: How is the development of the Sebalor Tourism Village into a Tourist Destination Area (DTW) and also wants to reveal several things that may be the driving and inhibiting factors for the development of the Sebalor Tourism Village into a Tourist Destination Area (DTW) in the Bandung District, Tulungagung Regency. . The research method in this study includes descriptive methods while the type of research is included in qualitative research. Data was collected using the methods of observation, interviews, and documentation. The subjects in this study were the Sebalor Village Government, Sebalor Village Community, Kali Mas and Watu Gedong visitors. Furthermore, data analysis in this study was carried out using qualitative analysis with data reduction steps, data presentation and conclusion drawing. The validity of the data in this study includes 1) credibility test, 2) transferability test, 3) dependability test, 4) confirmability test.
\end{abstract}

\section{Keywords: Sebalor Tourism Village Development, Tourist Destination}

\section{PENDAHULUAN}

Pengembangan suatu daerah dalam suatu proses pembangunan merupakan sesuatu yang terkait dan tidak dapat dilepaskan dari prinsip-prinsip otonomi daerah. Untuk mendukung penyelenggaraan otonomi daerah tersebut 
PUBLICIANA : JURNAL ILMU SOSIAL DAN ILMU POLITIK

VOLUME 14 NO 1

ISSN : $1979-0295$ | E-ISSN : $2502-7336$

dibutuhkan kewenangan yang luas, nyata, dan bertanggung jawab disetiap daerah. Oleh karena itu pariwisata perlu dikembangkan sebagai salah satu pemasukan bagi devisit negara dan menjadi sumber industri andalan. Sektor pariwisata selain dapat meningkatkan pertumbuhan ekonomi, juga dapat merusak lingkungan bahkan sebaliknya merangsang pelestarian lingkungan hidup. Hal ini dapat dimaklumi karena perkembangan pariwisata tidak dapat dipisahkan dari lingkungan hidup sebagai salah satu sarana atau objek wisata.

Pengembangan pariwisata pada intinnya merupakan suatu aktifitas yang menggali potensi pariwisata baik potensi sumber daya alam, sumber daya manusia maupun sumber daya buatan yang semua perlu dilakukan penanganan menyeluruh. (Argyo Demartoto, 2010:100). Pariwisata merupakan salah satu sektor yang bisa diandalkan dan sebagai prioritas dalam pengembangani suatu daerah. Dengan pengembangan daerah dalam hal ini pariwisatanya, diyakini daerah tersebut atau lebih khusus lagi pemerintah daerah tempat obyek wisata itu berada, akan mendapat pemasukan dari pendapatan setiap obyek wisata.

Pengembangan dan pendayagunaan pariwisata secara optimal mampu meningkatkan pertumbuhan ekonomi, mempertimbangkan hal tersebut maka penanganan yang baik sangat diperlukan dalam upaya pengembangan obyekobyek wisata di Indonesia. Para pelaku pariwisata mulai melakukan tindakan pengembangan dengan penelitian, observasi terhadap obyek-obyek wisata. Langkah tersebut dilakukan guna mengetahui potensi dan permasalahan yang ada pada setiap obyek untuk kemudian mencari solusinya.

Pengembangan Desa Sebalor diupayakan menjadi Desa Wisata sehaligus berharap menjadi Daerah Tujuan Wisata (DTW) dikawasan Kecamatan Bandung Kabupaten Tulungagung bahkan Indonesia memiliki potensi berkembang sebagai kawasan wisata masa depan. Dalam upaya pengembangan Desa Sebalor menjadi Daerah Tujuan Wisata (DTW) harus ada pemetaan, identifikasi potensi wisata. Karena yang diuntungkan adalah warga sendiri. Agar dapat mewujudkan Desa Sebalor menjadi Desa Wisata atau Daerah Tujuan Wisata (DTW) diperlukan beberapa syarat salah satunya adalah adanya partisipasi masyarakat. 
Pentingnya peran serta warga masyarakat diantaranya adalah : Pertama, fokus \& tujuan pengembangan desa wisata memerlukan kerlibatan mereka dalam mendukung program-prpgramnya. Kedua, harga diri, peningkatan harkat/martabat akan muncul dengan sendirinya. Ketiga, hak-hak individu dan keterlibatan dalam proses pengembangan dianggap sebagai pencerminan peran serta mereka. Keempat, kemampuan warga masyarakat dalam mewujudkan ciri kas daerah tergantung efektifitas partisipasi masyarakat.

Partisipasi masyarakat dianggap penting terkait proses pengembangan, hal ini diyakini bahwa berbagai masalah \& kebutuhan menyangkut lingkungan, masalah sosial ekonomi pasti diketahui oleh warga masyarakat itu sendiri, include didalamnya adalah masalah kepariwisataan. (Rahardjo Adisasmita 2013 : 80). Pemerintah Desa Sebalor beserta masyarakat sendiri dalam sumber dananya masih mengalami kesulitan karena dana yang diperoleh tidak mencukupi dalam upaya pembangunan ini. Sebab dana sendiri diperoleh dari dana desa kemudian dari hasil swadaya masyarakat. Kemudian kurangnya sumber daya manusia yang unggul dalam bidang pariwisata. Sebenarnya sudah dilakukan study banding ke Kota Batu.

Bertolak dari hal tersebut ingin diungkapkan bagaimana pengembangan Desa Sebalor menjadi Daerah Tujuan Wisata sekaligus juga faktor pendorong dan penghambat terkait Pengembangan Desa Sebalor menjadi Daerah Tujuan Wisata (DTW) di kawasan Kecamatan Bandung Kabupaten Tulungagung. Selain hal tersebut melaui penelitian diharapkan dapat menambah wawasan dan pola pikir serta pengembangan ilmu administrasi publik serta ilmuilmu sosial lainnya dalam memberikan kontribusi/pertimbangan pengambilan kebijakan terkait pengembangan pariwisata kususnya pemerintah Desa Sebalor serta pengelola Desa Wisata di Desa Sebalor menjadi Desa wisata/Daerah Tujuan Wisata (DTW), serta output studi ini dapat diperuntukkan sebagai acuan sekaligus nilai tambah yang dapat dikomparasikan dengan peneliti lain yang melakukan penelitian sejenis.

\section{KERANGKA TEORI}


PUBLICIANA : JURNAL ILMU SOSIAL DAN ILMU POLITIK

VOLUME 14 NO 1

ISSN : $1979-0295 \mid$ E-ISSN : $2502-7336$

Masyarakat pada umumnya memberikan pengertian istilah pengembangan dimaknai dengan perubahan sedikit demi sedikit (evolusi) yang terjadi secara perlahan. Pengembangan juga diartikan sebagai suatu proses untuk penterjemahan atau penjabaran karakteristil rancangan menuju pola-pola yang lebih realistik. (Seels \& Richey - Alim Sumarno, 2012).

Pengembangan diawali dengan peningkatan perekonomian yang mana warga mulai berkembang (upaya pengembangan) jika dapat melaksanakan suatu pembangunan dengan indikator pertumbuhan ekonomi. Produktivitas warga/masyarakat dalam hal ini rata-rata dalam satu tahunnya sebaga indikator/kriteria ukuran yang dipakai.(Rochajat, dkk, 2011, h.3. 

PUBLICIANA : JURNAL ILMU SOSIAL DAN ILMU POLITIK

VOLUME 14 NO 1

ISSN : $1979-0295$ | E-ISSN : $2502-7336$

Proses pengembangan pada umumnya mencakup 2 hal yakni pengembangan sarana fisik adalah pembanguan yang dapat di rasakan warga masyarakat serta yang tampak oleh mata sedangkan yang non fisik adalah yang dilakukan atas dorongan/keinginan masyarakat setempat. (Wresniwiro, 2012, h.23)

\section{A. Pariwisata}

Pariwisata seringkali dikaitkan dengan aktifitas touring yang dilakukan oleh individu/ kelompok dari satu tempat menuju tempat yang lain dalam periode tertentu. Perjalanan tersebut bertujuan bisa bersifat anjangsana, keagamaan, ilmiah, perdagangan maupun plesir semata. Ada salah seorang pakar yang menyatakan bahwa pariwisata terdiri atas tiga komponen yaitu wisatawan, elemen geografi dan industri pariwisata.(Leiper, https://cvinspireconsulting)

Istilah pariwisata dari hari ke hari terus berkembang seiring dengan perjalanan waktu. Istilah pariwisata mencakup pengertian dan bentuk pertanggungjawaban akan kelestarian lingkungan dari area alam yang alami (natural area), serta membawa hasil menurut pertimbangan ekonomis \& menjaga keaslian budaya setempat. Berdasarkan pernyataan diatas bisa dimaknai bahwa pariwisata merupakan pola aksi suatu pergerakan konservasi manusia di dunia.(https://cvinspireconsulting.com)

\section{B. Daerah Tujuan Wisata}

Daerah Tujuan Wisata (DTW) adalah suatu daerah tertentu yang ada komponen-komponen kepariwisataan (attraction, amenities, accebilities) dan layanan, serta unsur pendukung lainnya (masyarakat, pelaku industri pariwisata, dan institusi pengembang) yang membentuk sistem yang sinergis dalam menciptakan motivasi kunjungan serta totalitas pengalaman kunjungan bagi wisatawan. Selain itu pengertian mengenai tempat dimaksudkan sebagai destinasi/obyek yang memiliki daya tarik wisata, sarana penunjang wisata, infrastruktur atau prasarana yang dapat dibagi menjadi dua kategori yaitu yang memiliki batas administratif seperti negara, kabupatewn atau kota, kecamatan, desa dan lain lain, atau yang tidak memiliki batasan administratif atau lintas 
administratif seperti kawasan pariwisata. (https://sasmitadewianakagung.blogspot.com)

Destinasi Pariwisata diilustrasikan sebagai wilayah atau kawasan geografis yang berbeda dalam suatu atau lebih wilayah administratif yang di dalamnya terdapat unsur: daya tarik wisata, fasilitas pariwisata, aksesibilitas, masyarakat serta wisatawan yang saling terkait dan melengkapi untuk terwujudnya kegiatan kepariwisataan. (Hidayah, Pemasaranpariwisata.com). Daya tarik terbesar pada obyek wisata salah satunya terletak pada sebuah demontrasi, baik itu berupa pertunjukan kesenian, rekreasi, atau penyajian suatu paket kebudayaan kas setempat yang dijaga kelestariannya. Aktifitas hidup masyarakat sehari-hari yang tinggal sekitar obyek wisata memungkinkan untuk kontak dengan wisatawan via media (bahasa, isyarat tubuh, gerak/mimik wajah, atribut pakaian yang dipakai, perilaku unik), dan lain-lain.(Kementerian Kebudayaan dan Pariwisata, 2011, h.13) Terkait dengan perencanaan, pelaksanaan pembangunan \& pengembangannya ada beberapa hal yang perlu diperhatikan yakni :

a) Daya tarik wisata

a. Menurut peraturan perundang-undangan yang dimaksud dengan daya tarik wisata adalah segala sesuatu yang mengandung keunikan, keindahan, keanekaragaman \& kekayaan alam, budaya $\&$ kreatifitas manusia dalam mengelola kepariwisataan. (UU RI No 10 Tahun 2009 tentang kepariwisataan)

\section{b) Prasarana pariwisata}

a. Yang perlu dipertimbangkan dalam pengembangan prasarana wisata diantaranya adalah lokasi \& kondisi daerah, akses menuju obyek wisata dan daya tarik obyek wisata itu sendiri. Disamping itu kebutuhan lain yang perlu dipenuhi seperti seperti bank, apotik, rumah sakit, pom bensin, pusat-pusat pembelanjaan dan sebagainya

\section{c) Sarana Pariwisata}


a. Kelengkapan yang harus ada pada daerah tujuan wisata diantaranya adalah sarana wisata guna pelayanan wisatawan menikmati kunjungan wisatanya. Hal itu tentunya disesuaikan dengan kebutuhan wisatawan dan kemampuan pengelola obyek wisata. Trend yang lagi diminati wisatawan terkait keinginan kelengkapan sarana wisata memiliki pengaruh yang siknifikan terhadap kunjungan wisatawan diantaranya adalah hotel, transportasi, restoran, rumah makan dllnya, akan tetapi adanya sarana tersebut tentunya situasional dan mengikuti keperluan wisatawan.

\section{d) Tata laksana / infrastruktur}

Infrastruktur adalah situasi yang mendukung fungsi sarana dan prasarana wisata, baik yang berupa sistem pengaturan maupun bangunan fisik di atas permukaan tanah dan di bawah tanah seperti:

a. Sistem pengairan, distribusi air bersih, sistem pembuangan air limbah yang membantu sarana perhotelan/restoran.

b. Sumber listrik dan energi serta jaringan distribusinya yang merupakan bagian vital bagi terselenggaranya penyediaan sarana wisata yang memadai.

c. Sistem jalur angkutan dan terminal yang memadai dan lancar akan memudahkan wisatawan untuk mengunjungi objek-objek wisata.

d. Sistem komunikasi yang memudahkan para wisatawan untuk mendapatkan informasi maupun mengirimkan informasi scara tepat dan tepat.

e. Sistem keamanan atau pengawasan yang memberikan kemudahan di berbagai sektor bagi para wisatawan. Keamanan di terminal, diperjalanan dan di objek-objek wisata, di pusat-pusat perbelanjaan akan meningkatkan daya tarik suatu objek wisata maupun daerah tujuan wisata. (https://cvinspireconsulting.com).

\section{Masyarakat/ Lingkungan}

Warga/ penduduk setempat akan menerima kedatangan wisatawan \& menawarkan pelayanan yang diinginkan wisatawan. Warga/penduduk setempat perlu memahami macam \& mutu pelayanan yang diperlukan 
wisatawan. Terkait dengan itu maka pemerintah dan dinas terkait mengadakan arahan \& pelatihan yang berisi tentang pembinaan agar warga/penduduk menjadi sadar wisata.

\section{Pengembangan Kepariwisataan}

Pengembangan kepariwisataan adalah serangkaian usaha merealisasikan sumber-sumber daya pariwisata secara terpadu dalam beberapa aspek di luar dunia kepariwisataan baik langsung atau tidak langsung. Ada beberapa karakter unggul dari sektor pariwisata yang menjadikan sektor ini dapat mendongkrak peningkatan perekonomian pemerintah/daerah/masyarakat, adalah sebagai berikut :

a) Sektor kepariwisataan ibarat suatu industri memilik korelasi yang panjang dan mampu menjaga sinergitas pertumbuhan usaha mikro dengan home industry.

b) Sektor kepariwisataan dapat menampung sumber daya setempat (local resources based) utamanya bahan baku yang relative tidak akan pernah habis atau terbaharui (renewable resources).

c) Sektor kepariwisataan tidak akan pernah over-supply sebab memiliki spesifikasi produk yang khas dimana kondisi krisis/ resesi tidak begitu mempengaruhinya. (Sunaryo, 2013, h.35).

Investasi sarana \& prasarana pengembangan kepariwisataan meliputi pengelolaan disektor ini yakni penyediaan sumber daya air, penyediaan perumahan, trasnportasi, teknologi informasi. Investasi pendanaan dunia wisata mencakup pembangunan dan pengembangan bidang yang berorientasi pada perekonomian seperti lembaga keuangan badan pengelola KEK, Badan Otoritas, dan pelaku usaha di dalam obyek wisata. (tribunmanado.co.id).

Untuk mewujudkan tujuan pembangunan termasuk pengembangunan keparawisataan diperlukan perencanaan yang matang, pelaksanaan yang tepat, pengawasan yang maksimal.(Sunaryo, 2013, h.132)

\section{Partisipasi Masyarakat}


Partisipasi dimaknai sebagai keterlibatan masyarakat dalam suatu aktifitas baik dalam pernyataan maupun kegiatan. Selanjutnya ditegaskan bahwa partisipasi merupakan keikutsertaan masyarakat dalam programprogram pembangunan. Dari berbagai partisipasi masyarakat banyak hal yang dapat diserap, diantaranya rasa kompetisi, rasa tanggung jawab dan solidaritas.Partisipasi merupakan keikutsertaan seseorang didalam kelompok sosial untuk mengambil bagian dari kegiatan masyarakat yang ada, di luar pekerjaannya (Theodorson, 2010 dalam Putri, Astuti, \& Rahayu, 2016).

Selain itu, partisipasi masyarakat terkandung maksud peran serta dalam hal perencanaan oleh masyarakat, diawali dari proses analisa permasalahan, mencari solusi pemecahannya, menumbuhkan rasa percaya diri serta menentukan alternatif untuk memecahkan permasalahan. (Idajati, Pamungkas, \& Vely, 2016).

Beberapa klasifikasi dalam suatu peran serta/partisipasi diantaranya yaitu :

\section{Manipulative Participation/Partisipasi Manipulasi.}

Model partisipasi ini mempunyai ciri-ciri : keanggotaannya bersifat keterwakilan pada suatu komisi kerja, organisasi kerja, dan atau kelompok-kelompok. Jadi tidak berdasarkan pada partisipasi individu.

\section{Passive Partisipation/ Partisipasi Pasif.}

Apa yang telah diputuskan atau apa yang telah terjadi, informasi dari administrator tanpa mau mendengar tanggapan dari rakyat tentang keputusan atau informasi tersebut. Informasi tersebut hanya untuk mereka yang profesional saja.

\section{Partisipation by Consultation/ Partisipasi Melalui Konsultasi}

Dimaksudkan sebagai partisipasi untuk berkonsultasi atau menjawab pertanyaan. Awam mengartikan masalah-masalah dan proses pengumpulan informasi, dan mengawasi analisa. Pada partisipasi ini tidak ada pembagian dalam pengambilan keputusan, dan pendapat masyarakat serta mengabaikan orangluar.

\section{Partisipation for Material Incentives/Partisipasi Untuk Insentif}


Pada partisipasi ini bisa berbentuk dukungan berupa sumber daya, misalnya tenaga kerja, dukungan pangan, pendapatan atau insentif material lainnya. Pelibatan petani diantaranya adalah penyediakan lahan dan tenaga mereka, percobaan-percobaan \& pembelajaran. Keberlanjutan program ini tergantung pada keberlanjutan tersediaanya dana, apabila dana/incentif berhenti maka penguasaan teknologi juga berhenti.

\section{Function Participation/Partisipasi Fungsional}

Partisipasi dapat dilihat dari pencapaian target lembaga eksternal dalam upaya pencapaian tujuan akhir yakni pengurangan pendanaan. Partisipasi masyarakat dalam pembentukan kelompok terkait tujuan proyek terlihat cukup menarik, pengambilan keputusan tersebut diambil setelah keputusan utama.

\section{Interactive Participation/Partisipasi Interaktif}

Dalam hal masyarakat berpartisipasi dalam analisa kolektif tentang pengembangan perencanaan aksi dan pembentukan atau penekanan lembaga lokal. Partisipasi dapat dilihat sebagai suatu hak, ada beberapa cara untuk mencapai terget, hal ini dengan melibatkan multidisiplin metodologi dan model belajar terstruktur. Dalam pengambilan keputusan oleh kelompok setempat sangat menentukan tersediaanya sumber daya yang dipergunakan, dan pemerintah mempunyai kewenangan untuk mengawal keberadaan potens tersebut dalam lingkungan.

\section{Self-Mobilisation/ Partisipasi Inisiatif}

Partisipasi inisiatif dapat diilustrasikan adanya partisipasi yang tidak tergantung pada institusi dari luar dalam perubahan sistem. Interaksi dengan lembaga eksternal yang dikembangkan masyarakat untuk mendapatkan masukan tentang sumber daya dan cara-cara yang diperlukan, dan juga pengawasan penggunaan sumber daya tersebut. Hal ini dapat dikembangkan jika Pemerintah dan LSM hendaknya menyiapkan satu kerangka pemikiran yang sinergi dikembangkannya suatu kegiatan yang saling mendukung. (Oktami Dewi A. A. P Jurusan Antropologi, Makassar, 2013, h.10) 


\section{METODE PENELITIAN}

Metode penelitian yang dipakai dalam penelitian ini adalah metode penelitian kualitatif. Peneliti berupaya memberikan gambaran tentang realita sosial secara apa adanya mengenai fenomena yang ada pada masyarakat yang menjadi objek penelitian.

Langkah pada penelitian ini dimulai dengan pemilihan permasalahan, penentuan informasi yang diperlukan sesuai jenisnya, penentuan prosedur pengumpulan data dengan teknik observasi/pengamatan, pengolahan data serta penarikan kesimpulan.(Juliansyah Noor, 2015, h34)

Dalam penelitian kualitatif diasumsikan bahwa gejala dan obyek studi tersebut menyeluruh dan tidak terpisahkan sehingga didalam menetapkan penelitiannya tidak hanya didasarkan variabel penelitian saja melainkan didasarkan juga pada situasi sosial, tempat, pelaku, kegiatan yang berinteraksi \& bersinergis secara keseluruhan. (Sugiyono, 2012, h.207)

Didalam survey yang telah peneliti laksanakan, fokus penelitianya adalah :

1. Pembangunan daerah tujuan wisata dengan partisipasi masyarakat Desa Sebalor Kecamatan Bandung Kabupaten Tulungagung yaitu:

a) Wisata Watu Gedong

b) Wisata Kali Mas

2. Faktor pendorong dan penghambat Pembangunan daerah tujuan wisata dengan partisipasi masyarakat di desa Sebalor kecamatan Bandung kabupaten Tulungagung yaitu:

a) Factor Pendorong

(1) SDA

(2) Sebagai sumber pendapatan

(3) Diterbitkanya Undang Undang Nomor 10 Thn 2009 kepariwisataan

(4) Dukungan Pemerintah \& masyarakat

b) Factor Penghambat

(1) Keterbatasan dana 
(2) SDM

(3) Infrastruktur yang kurang memadai

(4) Menurunya jumlah wisatawan yang pesat

Alasan peneliti memilih Desa Sebalor sebagai tempat penelitian yaitu, Desa Sebalor memiliki beberapa potensi pariwisata serta termasuk Desa yang cukup getol untuk melakukan pengembangan Desa Wisata.

Sumber data dalam penelitian kualitatif adalah sebuah narasi \& sebuah perilaku, yang selanjutnya adalah suatu lampiran tambahan seperti dokumentasi, dll. Sumber data adalah individu/ seseorang atau sebuah situasi \& kondisi dipakai kerangka peneliti dalam melakukan pengumpulan data-data sesuai permasalahan \& fokus yang diteliti. (Moleong, 2011, h.157)

Adapun data yang ada pada penelitian diklasifikasikan sebagai berikut :

\section{Data Primer}

Dimaksudkan sebagai data yang dapat didapat dari informan/ responden yang terkait langsung. Data Primer yang dipergunakan diperoleh dari interview/wawancara. Data primer juga dapat berupa hasil wawancara dalam bentuk tulisan, rekaman, dokumentasi atau catatan dari obyek studi yang relevan dengan masalah yang diteliti.

Adapun sumber data primernya adalah beberapa narasumber diantaranya :
a) Kepala Desa Sebalor
b) Sekertaris Desa Sebalor
c) Ketua Pengelola
d) Masyarakat
e) Pengunjung

\section{Data Sekunder}

Data sekunder pada sebuah penelitian mempergunakan data yang sudah ada, yang kemudian oleh peneliti akan dimasukkan sebuah proses 
interpretasi \& analisis data yang telah ada itu sehingga dapat berkesesuaian dengan tujuan penelitian.

Adapun yang menjadi data sekunder dalam penelitian tersebut mencakup berkas-berkas selain data primer termasuk arsip \& catatan narasumber yaitu:

a) Data-data pengelola wisata

b) Data-data dari peneliti terdahulu

Peneliti dalam penelitian ini mempergunakan instrument penelitian diantaranya adalah :

1. Panduan wawancara, yakni panduan yang berisi draf/kisi-kisi materi yang sesuai dengan yang diteliti.

2. Notes, yakni berupa ringkasan hasil pengamatan, temuan pada obyek studi di lapangan yang disusun secara sistematis oleh peneliti.

3. Peneliti sendiri, yakni upaya untuk menyaksikan dan observasi langsung terhadap peristiwa \& obyek yang diteliti.

Data yang akurat dan lengkap yang diperoleh terkait pengembangan Desa Wisata Sebalor menjadi daerah tujuan wisata, maka data dikumpulkan melalui cara diantaranya :

\section{Pengamatan Langsung}

Pengamatan langsung adalah salah satu cara dikumpulkannya data \& gejala-gejala yang terlihat di lapangan dicatat peneliti yang turun ke obyek studi sebagai partisipan atau non partisipan. Hal tersebut memungkinkan diperoleh deskrepsi secara langsung, apa adanya tentang realita yang ada di obyek penelitian.

Dengan digunakannya observasi non partisipan oleh peneliti, maka observasi hanya dilakukan dari jauh. Pada pengamatan Non Partisipan peneliti tidak ikut membaur dengan masyarakat yang diamati tetapi hanya sebagai pengamat saja.

\section{Interview}


Teknik interview/lisan yakni narasumber yang kompeten diwawancarai peneliti sesuai dengan panduan interview/pedoman wawancara.

Teknik wawancara bebas yang dipergunakan dalam penelitian ini adalah wawancara yang pertanyaannya tidak dipersiapkan terlebih dahulu. Dengan kata lain dalam wawancara ini terjadi dialok interaktif secara spontanitas tergantung situasi \& kondisi yang ada, dan ini populer dikenal dengan istilah wawancara tidak berstruktur.

\section{Dokumentasi}

Dokumentasi yaitu dikumpulkannya data lewat buku/literatur terkait penelitian. Photo merupakan peralatan yang dipergunakan untuk dokumentasi. Cara yang dilakukan dengan mencatat, menyalin, data-data, berkas-berkas, laporan tertulis atau rekapitulasi barang-barang terkait survey serta pengambilan data lewat dokumen.

Analisa data dalam penelitian ini dimaksudkan sebagai upaya agar data menjadi lebih sederhana sehingga mudah untuk dibaca \& dipahami. Analisa data yang dipakai di penelitian ini adalah analisa kualitatif dengan model analisia interaktif dengan reduksi data, penyajian data, serta penarikan kesimpulan.

Dalam proses reduksi data adalah kegiatan untuk memilih, memusatkan, memperhatikan, menyederhanakan, mengabstraksikan, mentransformasikan data yang ditemukan dari obyek studi yang berlangsung dalam kegiatan penelitian serta berlangsung secara terus menerus. (Djunaidi dan Fauzan Alhansur, 2012, h.308)

Dalam penyajian data setelah informasi terkumpul hal ini memberikan kesempatan menarik simpulan \& tindakan. Setelah terjadinya data dapat disajikan, penelitian ini akan bisa diamati dan difahami oleh peneliti terkait apa yang sedang terjadi dan apa yang dilakukan.

Dari awal pengumpulan data, Peneliti harus memahami apa arti dari berbagai hal yang ditemui dengan melakukan pencatatan peraturan-peraturan, 
PUBLICIANA : JURNAL ILMU SOSIAL DAN ILMU POLITIK

VOLUME 14 NO 1

ISSN : $1979-0295$ | E-ISSN : $2502-7336$

pola-pola, pernyataan-pernyataan, arahan, sebab-akibat, dan berbagai proporsi, kesimpulan perlu diverifikasi sejak dari awal pengumpulan data agar survey dapat berjalan dan dilakukan dengan benar.

Penarikan kesimpulan dilakukan sesudah data semua terkumpul \& sudah tidak ada lagi informasi yang terkait dengan penelitian. Penarikan kesimpulan didukung dengan data-data yang valid yang dari dokumendokumen resmi sehingga kesimpulan yang dihasilkan peneliti dapat dipercaya.

Gambar: 1

Komponen-Komponen Analisa Data Model Interaktif

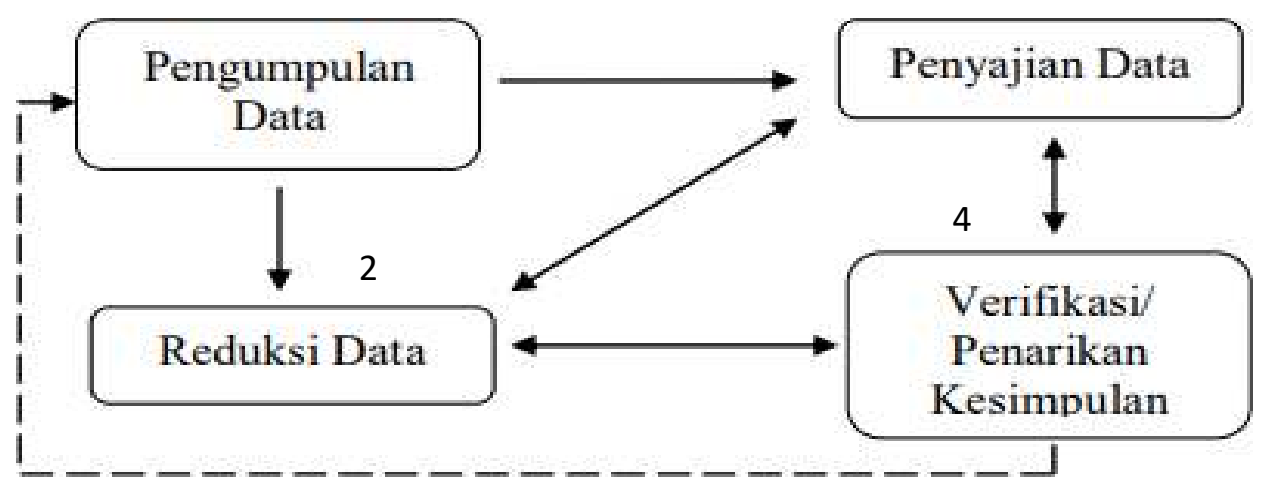

Sumber: Diagram Komponen dalam Analisis Data (Sugiyono, 2010 :337)

Keabsahan data adalah suatu tindakan untuk mengurangi penyimpangan pada upaya pencarian data dan tentunya berdampak dalam suatu suatu penelitian. Beberapa cara dalam upaya meningkatkan keabsahan data kualitatif adalah Kredibility, Transferability, Dependability dan Konfirmability.

Di penelitian ini ada beberapa cara yang ditempuh diantaranya adalah :

a) Test kepercayaan terhadap temuan dengan menambah waktu tinggal, pengamatan lebih jeli dan diuji secara triangulasi.

b) Pertemuan Pengarahan pada pertemuan kelompok penelitian guna mengatasi ketidak jelasan, kabur, dan lain-lain. 
c) Analisis kasus negative.

d) Test hasil temuan dan memberikan penafsiran.

e) Test terhadap temuan pada kelompok dari mana kita memperoleh data.

Kemudian terkait keteralihan yaitu apakah pada saat sekarang bisa menerapkan hasil penelitian terkini. Kredibility dalam hal ini sebagai pengganti validitas internal, transferability adalah sebagai validitas eksternal kemudian dependability sebagai substitusi istilah reability dan kemudian confirmability adalah sebagai substitusi adanya kepastian. Hal ini dilakukan peneliti dalam pendeskripsian penelitian dan melakukan asumsi yang menjadi pusat survey dimaksud. Sehingga peneliti akan lebih mudah dalam mendeskrepsikan hasil penelitiaannya.

Selanjutnya mengenai kebergantungan merupakan upaya pemeriksaan akurasi dan analisa data supaya derajat reabilitas tercapai memerlukan pemeriksaan terhadap seluruh komponen dan hasil penelitian, apakah konsistensi peneliti dalam pengumpulan data, pembentukan \& penggunaan pengertian dalam penginterpretasian data serta penarikan kesimpulan tercapai.

Kemudian mengenai confirmability pasti erat dengan objektifitas. Objektif adalah dapat dipercaya, sesuai fakta, pasti, sehingga bermula dari makna objektifitas suatu objek menjadi pasti.

Peneliti untuk menentukan kepastian data melakukan konfirmasi kepada narasumber kompeten. Kemudian hal yang dilakukan secara bersamaan adalah proses konfirmability dan pemeriksaan depandability. Proses konfirmability diperuntukkan melakukan penilaian hasil penelitian dengan dukungan bahan yang tersedia berkaitan deskrepsi, temuan \& pembahasan temuan penelitian. (Sugiono, $2010: 366$ )

\section{HASIL DAN PEMBAHASAN}

Kabupaten Tulungagung yang berbatasan dengan Kabupaten lain di Utara dengan Kabupaten Kediri, bagian Timur dengan Kabupaten Blitar, bagian Selatan dengan Samudra Indonesia, bagian Barat dengan Kabupaten Trenggalek dan Ponorogo. 
PUBLICIANA : JURNAL ILMU SOSIAL DAN ILMU POLITIK

VOLUME 14 NO 1

ISSN : $1979-0295$ | E-ISSN : $2502-7336$

Kabupaten Tulungagung luas wilayahnya secara keseluruhan seluas 1.055.65 Km2 atau seluas 105.565 Ha terinci sebagai berikut :

a) Areal seluas $\pm 35.353,72 \mathrm{Ha}$ atau $33,49 \%$ dengan ketinggian $0-100$ meter diatas permukaan air laut.

b) Areal seluas $\pm 58.926,38 \mathrm{Ha}$ atau 55,82\% dengan ketinggian 100-500 meter diatas permukaan air laut.

c) Areal seluas $\pm 8.096,84 \mathrm{Ha}$ atau $7,67 \%$ dengan ketinggian 500-1000 meter diatas permukaan air laut.

d) Areal seluas $\pm 3.188,06 \mathrm{Ha}$ atau 3,02\% dengan ketinggian lebih dari 1000 meter diatas permukaan air laut.

Kabupaten Tulungagung memiliki destinasi wisata yang beragam mulai dari wisata religi, wisata kuliner, wisata buatan, wisata alam \& budaya (paling dominan).

Tabel: 1

Perbandingan Jumlah dan Macam Daya Tarik Wisata di

Kabupaten Tulungagung

Tahun 2020

\begin{tabular}{|c|c|c|c|c|}
\hline \multirow[t]{2}{*}{ No } & \multicolumn{4}{|c|}{ Daya Tarik Wisata } \\
\hline & Budaya & Alam & Buatan & Desa Wisata \\
\hline 1 & Situs Alas Kebutan & Pantai Nglarap & $\begin{array}{l}\text { Industri } \\
\text { Marmer }\end{array}$ & Gamping \\
\hline 2 & $\begin{array}{l}\text { Situs Song } \\
\text { Gentong }\end{array}$ & Pantai Klatak & $\begin{array}{l}\text { Museum } \\
\text { Daerah }\end{array}$ & Wonorejo \\
\hline 3 & Makam Bedalem & Pantai Bayem & Masjid Tiban & Mulyosari \\
\hline 4 & Prasasti Lawadan & Pantai Sidem & $\begin{array}{c}\text { Argo Wisata } \\
\text { Belimbing }\end{array}$ & Sendang \\
\hline 5 & $\begin{array}{c}\text { Makam Mbah } \\
\text { Melinjo }\end{array}$ & Pantai Popoh & $\begin{array}{l}\text { Alun-Alun } \\
\text { Tulungagung }\end{array}$ & Sebalor \\
\hline 6 & Penemuan Fosil & Pantai Coro & $\begin{array}{c}\text { Taman } \\
\text { Kususma }\end{array}$ & \\
\hline
\end{tabular}


Pengembangan Desa Wisata Sebalor Menjadi Daerah Tujuan Wisata

\begin{tabular}{|c|c|c|c|c|}
\hline & & & Wicitra & \\
\hline 7 & $\begin{array}{l}\text { Monumen } \\
\text { Wajakensis }\end{array}$ & $\begin{array}{l}\text { Pantai Banyu } \\
\text { Muluk }\end{array}$ & $\begin{array}{c}\text { Kolam Renang } \\
\text { Srabah }\end{array}$ & \\
\hline 8 & Situs Watu Garit & $\begin{array}{c}\text { Pantai } \\
\text { Brumbun }\end{array}$ & $\begin{array}{c}\text { Waduk } \\
\text { Wonorejo }\end{array}$ & \\
\hline 9 & $\begin{array}{c}\text { Situs Lemah } \\
\text { Duwur }\end{array}$ & $\begin{array}{c}\text { Pantai } \\
\text { Gerangan }\end{array}$ & Argo Wilis & \\
\hline 10 & $\begin{array}{c}\text { Makam Petung } \\
\text { Ulung }\end{array}$ & Pantai Sanggar & & \\
\hline 11 & $\begin{array}{c}\text { Makam } \\
\text { Astonopraloyo }\end{array}$ & $\begin{array}{l}\text { Pantai Pathok } \\
\text { Gebang }\end{array}$ & & \\
\hline 12 & Makam Sengguruh & Pantai Sine & & \\
\hline 13 & Candi Nilosuwanro & Pantai Dlodo & & \\
\hline 14 & Makam Soka & $\begin{array}{c}\text { Pantai Kedung } \\
\text { tumpang }\end{array}$ & & \\
\hline 15 & Candi Tuban & $\begin{array}{c}\text { Pantai } \\
\text { Lumbung }\end{array}$ & & \\
\hline 16 & Situs Gembrong & Pantai Molang & & \\
\hline 17 & Candi Gambar & $\begin{array}{l}\text { Goa Pasetran } \\
\text { Gondomayit }\end{array}$ & & \\
\hline 18 & Makam Ngadirogo & Telaga Buret & & \\
\hline 19 & Candi Ampel & Goa Banyu & & \\
\hline 20 & Situs Kanigoro & Telaga Baran & & \\
\hline 21 & Situs Mbah Bodho & $\begin{array}{c}\text { Telaga } \\
\text { Ngambal }\end{array}$ & & \\
\hline 22 & Makam Surontani & $\begin{array}{c}\text { Air Terjun } \\
\text { Coban Kromo } \\
\text { (Indah) }\end{array}$ & & \\
\hline 23 & Candi Dadi & $\begin{array}{c}\text { Air Terjun } \\
\text { Alas }\end{array}$ & & \\
\hline
\end{tabular}


PUBLICIANA : JURNAL ILMU SOSIAL DAN ILMU POLITIK

VOLUME 14 NO 1

ISSN : 1979-0295 | E-ISSN : $2502-7336$

\begin{tabular}{|c|c|c|c|c|}
\hline & & Kadung & & \\
\hline 24 & Candi Cungkup & Goa Pasir & & \\
\hline 25 & Candi Sanggrahan & Goa & & \\
\hline & & Selomagleng & & \\
\hline 26 & Gunung Budeg & Goa Tritis & & \\
\hline 27 & Candi Sanggrahan & Goa & & \\
\hline & & Selomagleng & & \\
\hline 28 & Gunung Budeg & Goa Tritis & & \\
\hline 29 & Candi Gayatri & Pesanggrahan & & \\
\hline & & Argo Wilis & & \\
\hline 30 & Candi Boyolangu & Air Terjun & & \\
\hline & & Pandanwangi & & \\
\hline 31 & Makam Sunan & Air Terjun & & \\
\hline & Kuning & Lawean & & \\
\hline 32 & Makam Patih & Watu Gedong & & \\
\hline 33 & Makam Majan & Kali Mas & & \\
\hline 34 & Kuburan Wangi & Sumberece & & \\
\hline 35 & Makam Setono & & & \\
\hline & Gedong & & & \\
\hline 36 & Candi Asmoro & & & \\
\hline & Bangun & & & \\
\hline 37 & Situs Omben Jago & & & \\
\hline 38 & Situs Punden & & & \\
\hline & Gedong & & & \\
\hline 39 & Situs Kucur Sanga & & & \\
\hline 40 & Candi Panampihan & & & \\
\hline Juml & 40 wisata Budaya & 34 wisata alam & 9 Wisata & 5 Desa Wisata \\
\hline ah & & & Buatan & \\
\hline
\end{tabular}

Sumber: Dinas Pariwisata Kabupaten Tulungagung Tahun 2020 
Berdasarkan cerita dari nara sumber yang dapat kami percaya dan sekarang masih hidup,maka desa yang sekarang di sebut Sebalor itu dibuka (dibabat) kurang lebih pada taun 1873, dan sebagai pembabatnya (pendirinya) ialah seorang yang bernama Mbah Guru Eyang Djalaludin Sihab.Kemudian Beliau mendirikan suatu perguruan dengan nama Putuk Pengajaran.karena sang guru orang yang sakti dan mumpuni dalam ilmu lahir dan batin,maka banyaklah orang yang berguru kepadaNya.

Demikian banyaknya orang yang berguru maka diaturlah waktu menghadap sang guru, sehingga semua siswa dapat bertatap muka,guna mendapatkan wejangan ilmu seluruhnya.Dalam pengaturan Waktu tersebut siswa yang bersal dari utara perguruan harus menanti dalam bahasa jawa SEBO, dulu sebelum mendapat panggilan. Sehingga tempat menantinya (Sebo) para siswa dari bagian utara bahasa jawanya adalah LOR tersebut sampai sekarang terkenal dengan nama SEBALOR, yang maknanya PASEBON BAGIAN UTARA (LOR), Berubah ucapan menjadi SEBALOR dan akhirnya berubah ucapan lagi menjadi SEBALOR.

Sejak berdirinya desa Sebalor telah mengalami beberapa masa kepemimpinan, yaitu:
a) Bongso Rejo
b) Hiro Rejo
c) Sodiwiryo
d) Modin Karyo
e) Masino (1932 - 1935)
f) Sodimejo/wagimun $(1935-1965)$
g) Sokodiharjo/Sukidi $(1965-1990)$
h) Muhrodji Ibrahim (1990 - 2003)
i) Sukono $(2003-2008)$
j) Suyatno $(2008-2009)$
k) Moelyono (2010 - 2015)
1) Dadik Sukawiyatna (2015 - sekarang)

Diresmikannya pengembangan Desa Wisata Sebalor menjadi tujuan wisata pada tanggal 17 Nopember 2016, dengan mengusung tema keindahan pemandangan alam maka banyak orang jadi penasaran untuk berkunjung. Disana banyak spot menarik antara lain adalah kawasan wisata Watu Gedong, Kali Mas. 
PUBLICIANA : JURNAL ILMU SOSIAL DAN ILMU POLITIK

VOLUME 14 NO 1

ISSN : 1979 - 0295 | E-ISSN : $2502-7336$

Selain wisata utama desa sebalor memiliki destinasi pilihan lain yaitu Ancar Bangkong, Arena Berkuda, Arena Outbound, Budaya, Kuliner Khas Pawon tiwul dan atraksi budaya juga sejarah Desa Sebalor juga sangat menarik untuk diperbincangkan dan menjadi alternatif pengunjung, untuk menemukan penginapan juga dapat berkomunikasi dengan masyarakat.

Watu Gedong dan Kali Mas merupakan sebuah sungai di Tulungagung yang berasal dari sumber mata air yang mengalir melewati tebing-tebing batu bertingkat yang di sulap oleh seklompok pemuda, menjadi obyek wisata yang cukup menarik.

. Sepanjang lereng pegunungan desa ini ditemukan 29 mata air yang terus mengalir pada musim penghujan maupun musim kemarau. Suasananya seperti di Ubud Bali saja disana terhampar persawahan yang berkotak - kotak rapi dan ditemukan pepohonan yang rindang kayak menyongsong yang berkunjung untuk berwisata

Ada sebuah spot yang terdiri tebing-tebing besar dengan aksesoris alamnya berupa aliran air pegunungan yang mengalir dari ketinggian menyusuri tengah sungai kecil di tengah kokohnya tebing Tebing Besar dan kokoh ini ditemukan pada kawasan wisata Watu Gedong. Dalam istilah jawa Watu Gedong, kalo diindonesiakan berati batu gedung/gedung yang terbuat dari batu.

Selain Watu Gedong, pengunjung masih bisa spot lain yakni Wisata Kali Mas. Spot ini berupa air terjun, namun landai menyerupai kali/sungai, dengan warna dasarnya adalah kuning keemasan. Air pegunungan yang mengalir dari ketinggian menyentuh sisi-sisi sungai dengan warna kuning keemasan menyuguhkan pemandangan terasa menyegarkan mata, seolah seperti melambai-lambaikan tangan ke setiap wisatawan yang datang.

Proses pengembangan mengharapkan peningkatan perekonomian disertai progres growth plus change dari struktur ekonomi pertanian ke industri/jasa, perubahan kelembagaan, baik lewat regulasi maupun reformasi kelembagaan. Pengembang lebih dirasakan sebagai suatu usaha yang lebih rasional dan teratur bagi masyarakat yang masih/belum atau baru berkembang.(Subandi, 2011, h.9-11)

Dapat disimpulkan bahwa dalam tingkat perkembangan jumlah pengunjung mengalami penurunan yang disebabkan beberapa factor. Pengembangan desa wisata idealnya dilihat secara dinamis bukan dilihat secara statis. Pengembangan desa wisata yang masuk dalam cakupan orientasi \& aktifitas usaha tanpa akhir. Pembangunan desa adalah 
suatu proses perubahan sosial ekonomi, agar terjalin suatu proses kedepannya menjadi lebih baik diatas kekuatan sendiri dan tidak tergantung kepada pemerintah belaka.

Pengertian destinasi dimaksudkan sebagai area yang memiliki potensi untuk menarik wisatawan untuk berkunjung, tinggal sementara menikmati beberapa produk/spot pariwisata. (Tuohino \& Konu 2014)

Partisipasi masyarakat yaitu kehadiran seseorang/kelompok masyarakat baik dalam bentuk pernyataan maupun dalam bentuk kegiatan dengan memberi masukan pikiran, tenaga, waktu, keahlian, modal dan atau materi, serta ikut memanfaatkan dan menikmati hasil -hasil dalam proses pembangunan. (Sumaryadi 2010)

Oleh penulis disimpulan pembangunan daerah tujuan wisata dengan partisipasi masyarakat yaitu suatu pembangunan daerah tujuan wisata yang didalamnya ada sebuah partisipasi masyarakat guna membuat suatu perubahan dalam segi ekonomi maupun struktur daerah tujuan wisata yang bertujuan untuk menambah sumber pendapatan maupun untuk menanmbah daya tarik pengunjung.

a) Partisipasi masyarakat Desa Sebalor

Peran para masyarakat Desa Sebalor menyadari betapa besar potensi wisata di daerahnya berusaha karenaya penggalian, pengembangan serta pembangunan aset obyek \& daya tarik wisata, adalah modal awal untuk masyarakat Desa Sebalor sendiri. Hal ini harus ditindak lanjuti dengan pemikiran/mengusahakan pembenahan potensi dan daya tarik wisata.

Peranserta masyarakat dirasa sangat penting dalam proses pengembangan desa wisata. Penduduk desa Sebalor diharapkan peran sertanya dan dimotivasi untuk berperan aktif karena mereka pasti lebih tahu tentang masalah, kepentingan, serta kebutuhannya sendiri. Adanya peran Masyarakat di kawasan wisata juga ikut mendukung, serta kesadaran masyarakat akan pentingnya ikut menjaga dan memelihara daerah wisata menjadi kunci keberhasilan pengembangan pariwisata.

b) Faktor pendorong dan penghambat

Didalam proses pembangunannya pasti ada beberapa faktor yang mempengaruhi jalanya sebua pembangunan di Desa Wisata Sebalor. Ada dua faktor yaitu faktor pendukung dan faktor penghambat.

(1) Faktor pendukung 
PUBLICIANA : JURNAL ILMU SOSIAL DAN ILMU POLITIK

VOLUME 14 NO 1

ISSN : $1979-0295 \mid$ E-ISSN : $2502-7336$

Faktor Pendukung atau faktor pendorong adalah sebuah faktor yang bersifat mendukung, mengajak seseorang atau sebuah organisasi yang bertujuan untuk memudahkan suatu tujuan yang ingin dituju. (https://brainly.co.id)

Faktor pendukung yang mempengaruhi Pengembangan Desa Wisata Sebalor ,diantaranya :

(a) SDA

SDA dimaksudkan sebagai semua yang ada di alam dan dapat dipergunakan dan bermanfaat demi kelangsungan hidup manusia di dunia. SDA secara garis besar diklasifikasikan menjadi dua, yakni sumber daya yang dapat diperbaharui dan sumber daya alam yang tidak dapat diperbaharui, yang samasama memiliki manfaat untuk kehidupan manusia dan seyogyanya dimanfaatkan secara bijak untuk generasi mendatang. (https://www.mypurohith.com)

Masyarakat yang menyadari potensi SDA yang melimpah dapat dimanfaatkan \& menggali lebih dalam lagi SDA lain yang potensi dikembangkan kembali.

(b) Sumber Ekonomi

Berbicara dalam kontek perekonomian kepariwisataan, dimaksudkan sebagai upaya setiap daerah untuk mengembangkan sektor pariwisata dengan melibatkan masyarakat agar ikut andil, terjun, dan bergotongroyong dalam kegiatan tersebut. (https://www.kompasiana.com)

Begitu pula dengan Wisata Watu Gedong dan Kali Mas yang sedang dilakukan pengembangan, masyarakat Desa Sebalor diajak untuk ikut serta dalam pembangunan sebab nantinya masyarakat sendiri lah yang akan merasakan hasilnya. SDA yang digunakan sebagai modal tersebut dimanfaatkan seoptimal mungkin demi terselenggaranya kepariwisataan dengan tujuan untuk peningkatan pendapatan nasional, memperluas \& pemerataan kesempatan berusaha \& lapangan kerja, terdorongnya pembangunan daerah dengan memperkenalkan dan mendayagunakan daya tarik wisata dan destinasi wisata di daerah.(UU Nomor 10 Tahun 2009) 
Keberadaan Undang-Undang mengenai pariwisata juga sangat membantu menjadi pelindung dalam terealisasinya rencana pemerintah kususnya Pemerintah Desa Sebalor beserta masyarakat dalam upaya pengembangkan pariwisata.

(c) Dukungan pemerintah beserta masyarakat sekitar

Pemerintah bertanggung jawab atas empat hal utama yaitu yang pertama pemerintah sebagai perencana daerah atau kawasan pariwisata, kedua pemerintah sebagai pembangun fasilitas utama dan pendukung pariwisata, serta pemerintah sebagai pemutus kebijakan pariwisata, dan pembuatan dan penegakan peraturan. (https://subadra.wordpress.com). Salah satu bentuk dukungan pemerintah dalam pembangunan destinasi wisata ini pada akir tahun 2017 mendapatkan bantuan lapak dari DISPERINDAG Kab. Tulungagung. Sedangkan dari masyarakat sendiri terlihat adanya antusias mereka dalam berusaha meningkat potensi wisata yang ada disekitar Watu Gedong dan Kali Mas.

(2) Faktor penghambat

Faktor Penghambat dimaksudkan sebagai faktor yang bersifat menghalangi jalannya suatu proses/kegiatan dan bersifat seperti menggagalkan suatu hal.(https://brainly.co.id)

Dirasa ada beberapa faktor penghambat diantaranya adalah :

(a) Keterbatasan Dana.

Sumber dana pembangunan Desa Wisata Sebalor diperoleh dari suwadaya masyarakat dan pemerintah Desa Sebalor. Dana yang diharapkan dirasa masih belum mencukupi. Dana yang diberikan pemerintah sendiri kususnya dari Pemerintah Desa Sebalor diambilkan dari dana desa sedangkan dari dana desa sendiri tidah berfokus hanya pada satu keperluan saja.

(b) SDM

Kurangnya tenaga profesional yang ahli di bidang pariwisata itu sendiri manjadi faktor penghambat selanjutnya. Kurangnya pemahaman masyarakat dalam pengelolaan. Desa Wisata Sebalor sendiri terlihat tidak teratur dalam pengelolaanya. Dikarenakan pengetahuan bidang kepariwisataan di Sebalor sendiri masih minim.

(c) Infrastruktur yang kurang memadai 
PUBLICIANA : JURNAL ILMU SOSIAL DAN ILMU POLITIK

VOLUME 14 NO 1

ISSN : 1979 - 0295 | E-ISSN : $2502-7336$

Salah satu penunjang destinasi wisata salahsatunya adalah infrastruktur yang memadai. Permasalahan sekaligus penghambat dalam pembangunan Desa Wisata Sebalor yaitu infrastruktur yang kurang memadai. Pembangunan infrastruktur disebagian tempat terlihat terhenti begitusaja dan kesanya sebagian bangunan tidak terawat.

(d) Menurunya jumlah wisatawan

Awal dibangunya wisata ini sampai sekarang jumlah pengunjung relatif mengalami penurunan. Hal ini mungkin disebabkan adanya pesaing baru (bermunculannya tempat-tempat wisata baru) yang lebih gencar promonya karena dukungan pendanaan.

\section{KESIMPULAN}

Potensi pariwisata di wilayah Kabupaten Tulungagung begitu banyak memiliki destinasi wisata yang prospektif dan sangat menjanjikan apabila dikelola dan dikembangkan. Diperlukan banyak upaya dan perhatian khusus untuk membuat potensi tersebut menjadi sumber penggerak ekonomi masyarakat. Berdasarkan realita di lapangan didukung datadata/informasi yang peneliti peroleh dari informan/narasumber sehingga dapat diambil kesimpulan sebagai berikut:

Kekayaan alam pada Desa Wisata Sebalor memiliki potensi untuk berkembang menjadi objek wisata. Upaya dan partisipasi dalam pengembangan daerah ini, pemerintah beserta masyarakat Desa Sebalor menyadari betapa besarnya potensi kepariwisataan di daerah tersebut untuk digali dan dikembangkan demi peningkatan kesejahteraan dan kemakmuran warga masyarakat Desa Sebalor.

Upaya pemerintah beserta masyarakat Desa Sebalor sedikit demi sedikit mulai menampakkan hasilnya. Fasilitas penunjang sebagian sudah terbangun meski sebagian masih setengah jadi. Tingkat partisipasi/antusiasme masyarakat cukup tinggi, ini merupakan indikator dari kesadaran mereka untuk memajukan Desa Sebalor.

Dalam pengembangan Desa Wisata Sebalor menjadi daerah tujuan wisata tentunya pasti ada beberapa faktor yang berpengaruh diantaranya adalah :

a) Faktor Pendorong :

(1) Pertama sumber daya alam yang dimiliki Desa Wisata Sebalor begitu melimpah yang berpotensi untuk di jadikan sebagai daerah tujuan wisata. 
(2) Selanjutnya yang kedua yaitu sebagai salah satu sumber pendapatan dari masyarakat. Disini masyarakat sadar jika ini dikembangkan akan menjadi sumber pendapatan mereka maka mereka terdorong untuk ikut berpartisipasi dalam pembangunan ini.

(3) Ketiga dengan diterbitkannya UU No 10 Thn 2009 yang berisi tentang kepariwisataan merupakan payung hukum pembangunan Desa Wisata Sebalor.

(4) Keempat dukungan pemerintah daerah \& masyarakat desa sekitar sangat antusias dalam pembangunan desa wisata ini. Mereka termotifasi karena adanya dukungan dari segala pihak.

b) Faktor Penghambat

(1) salah satunya dari kepemilikan dana dalam pengembangan Desa Wisata Sebalor menjadi daerah tujuan wisata masih terbatas, Pemerintah beserta masyarakat desa masih kesulitan dalam mendapatkan sumber pendanaan.

(2) Kedua kekurangan tenaga profesional yang ahli dalam bidang kepariwisataan. Masyarakat Desa Sebalor sendiri saat ini belum memiliki SDA yang ahli dalam bidang kepariwisataan.

(3) Ketiga kurangnya infrastruktur yang memadai. Dari akses jalan menuju Watu Gedong curam, kemudian dari fasilitas pendukung lain dirasa kurang terawatt disebabkan sebagian fasilitas setengah jadi.

(4) Keempat menurunya jumlah wisatawan yang pesat. Faktor ini kemungkinan terjadi karena dipengaruhi beberapa factor salah satunya tren disosial media, kemudian dari segi infrastruktur wisata ini membuat pengunjung kurang nyaman.

\section{REKOMENDASI}

Makna pengembangan adalah bersifat bergerak tanpa akhir (Dinamis) maka pengembangan Desa Wisata Sebalor menjadi daerah tujuan wisata tidak hanya dilihat dari konsep yang terhenti (Statis). Sebuah upaya pengembangan merupakan orientasi \& aktifitas usaha yang tidak akan berhenti. Didalamnya harus mengacu pada upaya perubahan sosial yang mencakup suatu proses yang dapat berlangsung diatas kekuatan sendiri tidak tergantung struktur sosial \& manusianya. Pengembangan Desa Wisata Sebalor diharapkan mengalami pergerakan maju serta melakukan kegiatan usaha tanpa akhir dalam pembangunannya agar dapat diartikan pengembangan Desa Wisata Sebalor telah berhasil. 
PUBLICIANA : JURNAL ILMU SOSIAL DAN ILMU POLITIK

VOLUME 14 NO 1

ISSN : 1979 - 0295 | E-ISSN : $2502-7336$

Diharapkan pemerintah sendiri nantinya dalam anggaran dibidang pariwisata ditinjau kembali, sebab potensi pariwisata di Indonesia sangat besar dalam upaya menambah sumber pendapatan daerah serta dalam meningkatkan kesejahteraan masyarakat.

Kedepanya diharapkan demi keberlanjutan dalam pengembangan Desa Wisata Sebalor menjadi daerah tujuan wisata, pemerinta desa Sebalor beserta masyarakat harus mencari solusi dalam masalah kurangnya SDA yang ahli dalam bidang kepariwisataan mungkin dengan mengadakan pelatihan dalam pendalaman kepariwisataan. Sumber daya manusia sangat berpengaruh sekali dalam upaya pengembangan kedepan, kemudian infrastruktur juga terlihat kurang memadai, hal ini seharusnya pemerintah beserta masyarakat bekerja sama bahu-membahun untuk menciptakan situasi yang kondusif.

\section{DAFTAR PUSTAKA}

\section{A. Buku}

Argyo Demartoto. 2009. Pembangunan Pariwisata Berbasis Masyarakat. Surakarta: UNS Press.

Adisasmita, Rahardjo. 2013. Teori-Teori Pembangunan Ekonomi. Yogyakarta: Graha Ilmu. Harun, Rochajat., \& Ardianto, Elvinaro. 2011. Komunikasi Pembangunan \& Perubahan Sosial: Perspektif Dominan, Kaji Ulang, dan Teori Kritis. Rajawali Pers, Jakarta.

Husaini Usman dan Purnomo Setiady Akbar. 2009. Metode Penelitian Sosial. Jakarta: PT Bumi Aksara.

Idajati, H., Pamungkas, A., \& Vely, K. S. 2016. The Level of Participation in MangroveEcotourism Development, Wonorejo Surabaya. Procedia - Socia and Behavioral Sciences, 227, 515-520.doi:10.1016/j.sbspro.2016.06.109

Kuncoro, Mudrajad. 2010. Dasar-dasar Ekonometrika Pembangunan. UPP STIM YKPN. Moleong, L. J. 2011. Metodologi Penelitian Kualitatif. Bandung: PT. Remaja Rosda Karya. Nasdian, F. T. 2014. Pengembangan masyarakat. Jakarta: Yayasan Pustaka Obor Indonesia. Oktami Dewi A. A. P. Partisipasi Masyarakat dalam Pengembangan Objek Wisata Bahari Di Pulau Kapoposang Kabupaten Pangkajene dan Kepulauan.Skripsi Fakultas Ilmu 
Sosial dan Ilmu Politik, Jurusan Antropologi.Makassar Universitas Hasanuddin.2013, hal : 10

Putri, R. A., Astuti, W., \& Rahayu, M. J. 2016. Community Capacity in Providing Neighborhood Unit-scale Social Infrastructure in Supporting Surakarta Child Friendly. Procedia - Social and Behavioral Sciences, 227, 536-544. doi:10.1016/j.sbspro.2016.06.112

Sumodiningrat, Gunawan. 2009. Mewujudkan Kesejahteraan Bangsa. Elex Media Komputindo. Jakarta.

Sunaryo, Bambang. 2013. Kebijakan Pembangunan Destinasi Parawisata: Konsep dan aplikasinya di Indonesia. Gava Media: Yogyakarta.

Surya Arif Wijaya, Zulkarnain, Sopingi Jurnal Pendidikan Nonformal Volume XI, No. 2, September 2016

Supriyono, Rachmat. 2010. Desain Komunikasi Visual, Yogyakarta: Andi Offset.

Sugiyono. 2012. Metode Penelitian Kuantitatif Kualitatif dan R\&D. Bandung: Alfabeta.

Sugiyono, 2013, Metodelogi Penelitian Kuantitatif, Kualitatif Dan R\&D. Bandung: ALFABETA

Wresniwiro, 2012, Membangun Republlik Desa, Jakarta, Visimedia.

Wardiyanto dan Baiquni. 2011 Perencanaan Pembangunan Pariwisata. Bandung : Lubus Agung.

konsep-pengembangan-pariwisata Kementerian Kebudayaan dan Pariwisata, 2011: 13

\section{B. Peraturan Perundang-undangan}

Peraturan Menteri Perhubungan No. 121 tahun 2015.

Perpres No.21/2016 Kebijakan mengenai bebas visa kunjungan

UUD 1945 pasal 33 ayat 3 tentang Perekonomian

Undang-undang nomor 10 Tahun 2009 tentang Kepariwisataan, pariwisata.

Undang-Undang Nomor 32 Tahun 2004 tentang Otonomi Daerah.

\section{Internet}

https://media.neliti.com/strategi-pengembangan-pariwisata/ diakses 21 feb 2020 
PUBLICIANA : JURNAL ILMU SOSIAL DAN ILMU POLITIK

VOLUME 14 NO 1

ISSN : 1979 - 0295 | E-ISSN : 2502 - 7336

https://sasmitadewianakagung.blogspot.com/diakses pada 23 mei 2020

https://www.slideshare.net/dianaHabibah/metodologi-penelitian-bab-813/ diakses 21 feb 2020

https://manado.tribunnews.com/diakses pada 23 mei 2020

http://ejournal2.undip.ac.id/index.php/jpkDOI:10.14710/jpk.6.2.108-117/ diakses 12 maret 2020

http://www.koran-pagi.net/2019/08/koranpagi_10.html/_diakses 23 mei 2020

https://id.wikipedia.org/wiki/Kabupaten_Tulungagung/diakses 23 mei 2020

http://36.66.171.205:8181/inlislite3/opac/detail-opac?id=2085/ diakses 21 feb 2020

https://pemasaranpariwisata.com/2019/10/12/destinasi-adalah/diakses 21 feb 2020

http://www.berdesa.com/bangun-wisata-desa-pokdarwis-terbukti/diakses 1 Ags 2020

https://www.kajianpustaka.com/2020/01/partisipasi-masyarakat.html/ diakses 12 februari 2020

https://brainly.co.id/tugas/17446883\#readmore / diakses 23 mei 2020

https://www.mypurohith.com/term/sumber-daya-alam/diakses 21 juni 2020

https://cvinspireconsulting.com/konsep-pengembangan-pariwisata/diakses 27 juli 2020

https://www.kompasiana.com/safirahalidaziah / diakses 27 Juli 2020 